\title{
Isolatable organophosphorus(III)-tellurium heterocycles
}

\author{
Andreas Nordheider $^{[\mathrm{a}, \mathrm{b}]}$, Tristram Chivers ${ }^{[\mathrm{b}]}$, Oliver Schön ${ }^{[\mathrm{cl}]}$, Konstantin Karaghiosoff ${ }^{[\mathrm{cl}]}$, Kasun S \\ Athukorala Arachchige ${ }^{[a]}$, Alexandra M. Z. Slawin ${ }^{[a]}$ and J. Derek Woollins ${ }^{[\mathrm{a}] *}$
}

A new structural arrangement $\mathrm{Te}_{3}\left(\mathrm{RP}^{\mathrm{III}}\right)_{3}$ and the first crystal structures of organophosphorus(III)-tellurium heterocycles are presented. The heterocycles can be stabilized and structurally characterized by (a) the appropriate choice of substituents in $\mathrm{Te}_{\mathrm{m}}\left(\mathrm{P}^{\mathrm{III}} \mathrm{R}\right)_{\mathrm{n}}\left(\mathrm{m}=1: \mathrm{n}=2, \mathrm{R}=\right.$ OMes $^{*} ; \mathrm{n}=3, \mathrm{R}=\mathrm{Ad} ; \mathrm{n}=4, \mathrm{R}=\mathrm{Fc} ; \mathrm{m}=\mathrm{n}=3: \mathrm{R}=$ Trt, Mes*) or (b) the installation of a $\mathrm{P}^{\mathrm{V}}{ }_{2} \mathrm{~N}_{2}$ anchor in $\mathrm{RP}^{\mathrm{III}}\left[\mathrm{TeP}^{\mathrm{V}}(t \mathrm{BuN})(\mu-\mathrm{N} t \mathrm{Bu})\right]_{2}(\mathrm{R}=\mathrm{Ad}, t \mathrm{Bu})$.

Keywords: heterocycles $\cdot$ NMR-
spectroscopy $\cdot$ phosphorus
tellurium $\cdot$ X-ray diffraction

\section{Introduction}

Compounds such as Lawesson's reagent $\left[\left(4-\mathrm{MeOC}_{6} \mathrm{H}_{4}\right) \mathrm{P}=\mathrm{S}(\mu-\mathrm{S})\right]_{2}$ $(\mathbf{L R})^{1}$ and Woollins' reagent $[\mathrm{PhP}=\mathrm{Se}(\mu-\mathrm{Se})]_{2}(\mathbf{W R})^{2}$ illustrate that organophosphorus-sulfur and -selenium compounds have been studied extensively not least because of their interesting reactivity towards organic compounds. ${ }^{3,4}$ In contrast, organophosphorustellurium heterocyles $(\mathrm{RP})_{\mathrm{n}} \mathrm{Te}_{\mathrm{m}}$ have been only sporadically investigated. ${ }^{5}$ The systems were usually obtained as mixtures and characterized by a combination of solution-state ${ }^{31} \mathrm{P}$ and ${ }^{125} \mathrm{Te}$ NMR as well as mass spectrometry. ${ }^{6-9}$

The different synthetic approaches that were developed to generate organophosphorus(III)-tellurium heterocycles include reactions of

(a) $\mathrm{RP}-\mathrm{Si}$ reagents $[\mathrm{R}=t \mathrm{Bu}]$ with tellurium ${ }^{6,7}$

(b) $\mathrm{RPCl}_{2}\left[\mathrm{R}=t \mathrm{Bu}, \mathrm{R}_{2}{ }_{2} \mathrm{~N}\left(\mathrm{R}^{\prime}=i \mathrm{Pr}, \mathrm{Cy}, \mathrm{Ph}\right)\right]$ with $\mathrm{Na}_{2} \mathrm{Te}, \mathrm{Li}_{2} \mathrm{Te}_{2}$ or $\mathrm{Te}\left(\mathrm{SiMe}_{3}\right)_{2}{ }^{6-9}$

(c) $t \mathrm{Bu}(\mathrm{Cl}) \mathrm{P}-\mathrm{P}(\mathrm{Cl}) t \mathrm{Bu}$ with $\mathrm{Na}_{2} \mathrm{Te}^{5,6}$ or

(d) $n \mathrm{Bu}_{3} \mathrm{PTe}$ with the diphosphene $\mathrm{TbtP}=\mathrm{PFc} \quad(\mathrm{Tbt}=2,4,6-$ tris[bis(trimethylsilyl)methyl]-phenyl) ${ }^{10}$

These pathways produced a series of organophosphorus(III)tellurium heterocycles with different structural arrangements, as depicted in Figure 1. So far, the findings regarding these systems by $\mathrm{du}$ Mont $^{6,7}$, Karaghiosoff ${ }^{8,9}$ and Tokitoh ${ }^{10}$ lead to the following conclusions:

(i) 3-, 4- and 5- membered rings containing one Te atom and 5and 6-membered ring incorporating one $\mathrm{Te}-\mathrm{P}^{\mathrm{III}}-\mathrm{Te}$ unit and two $\mathrm{P}^{\mathrm{III}}-\mathrm{Te}-\mathrm{P}^{\mathrm{III}}$ units, respectively, are possible (see Figure 1, left-hand and centre columns)

[a] EaStCHEM School of Chemistry

University of St Andrews,

St Andrews, Fife, KY16 9ST, UK

Fax: (+44) 01334 463834;

E-mail: jdw3@st-and.ac.uk

[b] Department of Chemistry, University of Calgary, Calgary, AB, Canada T2N 1N4

[c] Department of Chemistry and Pharmacy, University of Munich, Munich-

Grosshadern, 81377, Germany

Supporting information for this article is available on the WWW (ii) stable heterocycles containing both terminal (exo) and bridging (endo) $\mathrm{Te}$ atoms, i.e. a $\mathrm{P}=\mathrm{Te}(\mu-\mathrm{Te})$ unit, cf. $\mathbf{L R}$ and WR, are unlikely

(iii) $\mathrm{CF}_{3}$ substituents on $\mathrm{P}$ improve the stability of the rings with respect to loss of Te in solution, whereas $\mathrm{NR}_{2}$ groups do not have the same stabilizing influence

(iv) the pure 3- and 4-membered rings that were isolated $(t \mathrm{BuP})_{\mathrm{n}} \mathrm{Te}$ $(\mathrm{n}=2,3)$ are yellow or red liquids at RT

(v) the reported compounds are air-sensitive, some show lightsensitivity and thermal instability, which complicates the isolation and characterization

(vi) no solid-state structures have been reported.

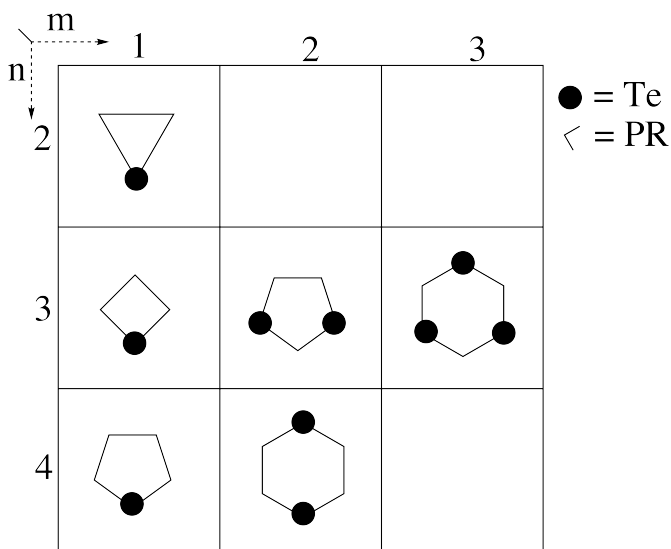

Figure 1. Structural arrangements of organophosphorus(III)-tellurium heterocycles $(\mathrm{RP})_{\mathrm{n}} \mathrm{Te}_{\mathrm{m}}$, including this work. The existence of $\mathrm{Te}_{2}(\mathrm{RP})_{4}$ is tentative based on limited NMR data.

In this paper we describe two new synthetic approaches to organophosphorus(III)-tellurium heterocycles that have led to (a) the first examples of ring systems that incorporate an equal number of alternating $\mathrm{P}$ and $\mathrm{Te}$ atoms, i.e. $\mathrm{Te}_{3}(\mathrm{PR})_{3}\left(\mathrm{R}=\mathrm{Mes}^{*}\right.$, Trt; Trt $=$ trityl $=-\mathrm{CPh}_{3}$ ), (b) the first solid-state structural characterizations of $\mathrm{Te}_{\mathrm{m}}(\mathrm{RP})_{\mathrm{n}}$ rings including $\mathrm{Te}_{3}(\mathrm{PR})_{3}, \mathrm{Te}(\mathrm{PR})_{2}\left(\mathrm{R}=\mathrm{OMes}^{*}\right), \mathrm{Te}(\mathrm{PR})_{3}$ $(\mathrm{R}=\mathrm{Ad}) \mathrm{Te}(\mathrm{PR})_{4} \quad(\mathrm{R}=\mathrm{Fc})$, and (c) $\mathrm{P}_{2} \mathrm{~N}_{2}$-stabilized organophosphorus(III)-tellurium rings. 


\section{Results and discussion}

\section{Synthesis and multinuclear NMR spectra of organophosphorus(III)-tellurium heterocycles}

The first synthetic approach involves the reaction of $\mathrm{RPCl}_{2}(\mathrm{R}=\mathrm{Fc}$, Ad, Mes*O, Mes*, Trt) with $\mathrm{Na}_{2} \mathrm{Te}_{2}$ in THF (Scheme 1). These R groups were chosen since they provide significant steric bulk (Mes*, Trt) and the Fc analogue of $\mathbf{L R}$ has proved to be very stable. ${ }^{11}$ Furthermore, an adamantyl ligand at a phosphorus atom was shown to have similar reactivity and characteristics to the tert-butyl ligands. The reactions of the adamantyl-substituted compounds are usually slower but crystallization is favored in comparison to tert-butyl compounds. ${ }^{12}$ The Mes*O substituent was used as an example of a bulky electronegative anionic ligand system at the phosphorus atom.

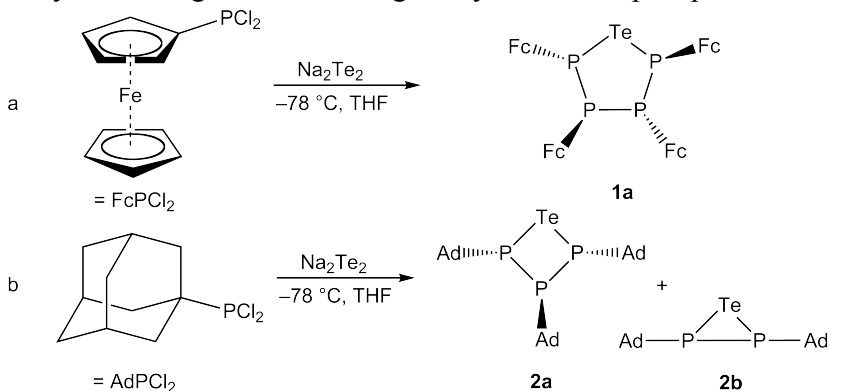

Scheme 1. Reaction of (a) $\mathrm{FcPCl}_{2}$ and (b) $\mathrm{AdPCl}_{2}$ with $\mathrm{Na}_{2} \mathrm{Te}_{2}$ in THF.

Treatment of $\mathrm{FcPCl}_{2}$ with an equimolar amount of $\mathrm{Na}_{2} \mathrm{Te}_{2}$ in THF at $-78{ }^{\circ} \mathrm{C}$ produced $1 \mathrm{a}$ as the major product with the cyclopentaphosphane $(\mathrm{FcP})_{5}^{13}$ as a by-product, which was identified by X-Ray crystallography. The 2,3,4,5-tetra-ferrocenyl-1-tellura2,3,4,5-tetraphospholane 1a was isolated as an orange to red solid with low solubility, which can however be recrystallized from hot toluene to yield pure 1a in low yield. By contrast, the reaction of $\mathrm{AdPCl}_{2}$ with $\mathrm{Na}_{2} \mathrm{Te}_{2}$ under similar conditions yielded the telluradiphosphirane $\mathbf{2 b}$ as the main product and the telluratriphosphetane 2a as a minor product $\left({ }^{31} \mathrm{P} \mathrm{NMR}\right)$; 2a was isolated as red crystals in ca. $5 \%$ yield. ${ }^{14}$

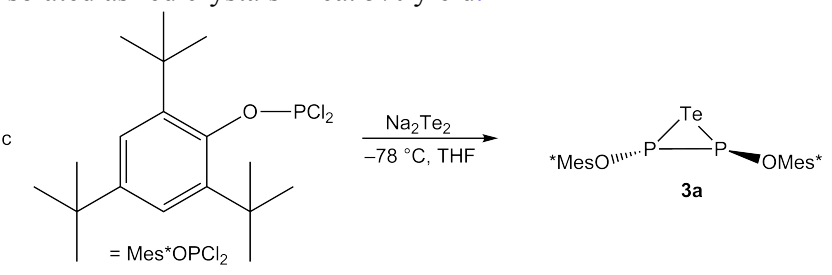

Scheme 2. Reaction of $\mathrm{Mes}^{*} \mathrm{OPCl}_{2}$ with $\mathrm{Na}_{2} \mathrm{Te}_{2}$ in THF.

Similarly $\mathrm{Mes}^{*} \mathrm{OPCl}_{2}$ was reacted with $\mathrm{Na}_{2} \mathrm{Te}_{2}$ to yield the telluradiphosphirane 3a, which was isolated in a yield of $37 \%$ after recrystallization from hexane.

Finally, the reaction of $\mathrm{Mes}^{*} \mathrm{PCl}_{2}$ and $\mathrm{TrtPCl} \mathrm{Pl}_{2}$ with an equimolar amount of $\mathrm{Na}_{2} \mathrm{Te}_{2}$ gave rise to the novel tritelluratriphosphorinanes 4a (Mes*PTe $)_{3}$ and 5a (TrtPTe $)_{3}$, which were characterized by NMR spectroscopy. For the reaction with $\mathrm{Mes}^{*} \mathrm{PCl}_{2}$ the disphosphene (Mes*P=PMes*) ${ }^{*}$ was observed as a major byproduct and together with elemental Te also as the decomposition product, when left in solution for more than $24 \mathrm{~h}$. For the $\mathrm{TrtPCl}_{2}$ reactions a telluratriphosphetane $\mathbf{5 b}$ was identified as a minor product besides other unknown compounds. In contrast to $\mathbf{1 a}, \mathbf{2 a}, \mathbf{2 b}$ and 3a these compounds (4a, 5a, 5b) are highly air sensitive and slightly light sensitive.
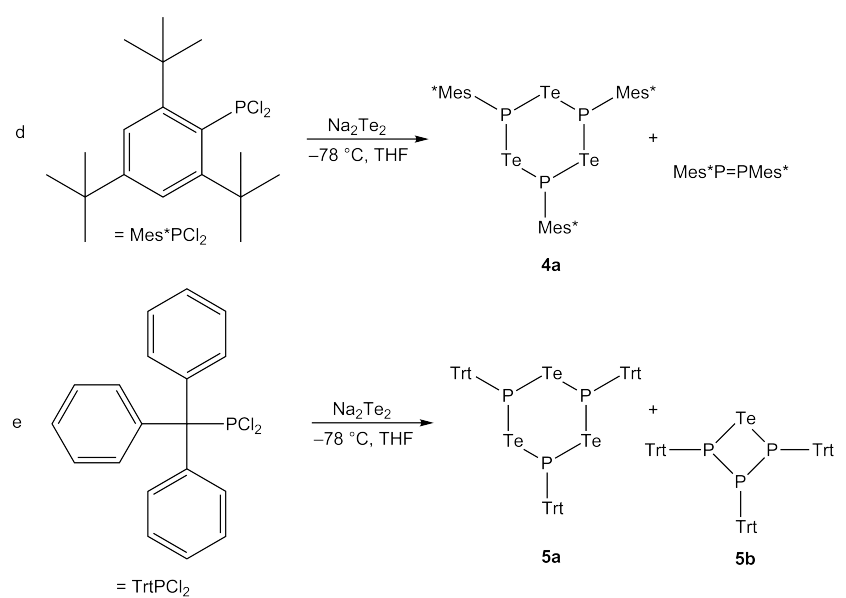

Scheme 3. Reaction of d) $\mathrm{Mes}^{*} \mathrm{PCl}_{2}$ and e) $\mathrm{TrtPCl}_{2}$ with $\mathrm{Na}_{2} \mathrm{Te}_{2}$ in THF.

The ${ }^{31} \mathrm{P}$ NMR spectrum of 1a exhibits a second order AA'MM' pattern (considering the ${ }^{125} \mathrm{Te}$-containing isotopomer it expands to an $\mathrm{AA}^{\prime} \mathrm{MM}$ 'X spin system). The characteristic values (shift and coupling constants) were calculated by iterative fitting as shown in Figure 2.

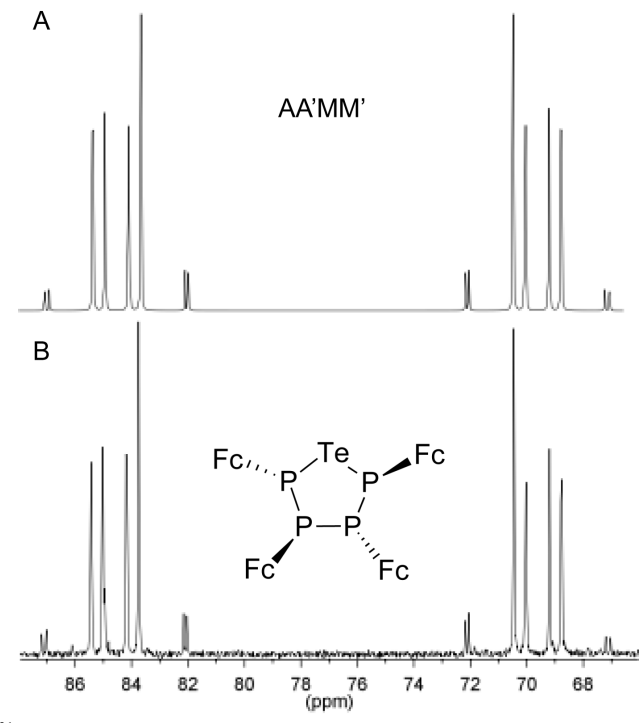

Figure 2. ${ }^{31} \mathrm{P}$ NMR spectrum $(202.47 \mathrm{MHz})$ of 1a: (A) AA'MM' spectrum calculated by iterative fitting, (B) experimental spectrum. ${ }^{16}$

The $\mathrm{P} 1 / \mathrm{P} 1$ ' resonances appear at $84.5 \mathrm{ppm}$ revealing a ${ }^{1} J_{\mathrm{P} 1-\mathrm{P} 2^{-}}$ coupling of $-305.1 \mathrm{~Hz}, \mathrm{a}^{2} J_{\mathrm{P} 1-\mathrm{P} 2} / \mathrm{P}^{\prime}-\mathrm{P} 2$-coupling of $31.0 \mathrm{~Hz}$ and a ${ }^{2} J_{\mathrm{P} 1-\mathrm{Pl}}$-coupling of $8.0 \mathrm{~Hz}$. The $\mathrm{P} 2 / \mathrm{P} 2$ ' resonances are observable at $69.6 \mathrm{ppm}$ with a ${ }^{l} J_{\mathrm{P} 2-\mathrm{P} 2}$--coupling of $-339.0 \mathrm{~Hz} .{ }^{17}$ The very poor solubility of 1a precluded the observation of ${ }^{125} \mathrm{Te}$ satellites as well as characterization by ${ }^{125} \mathrm{Te} \mathrm{NMR}$.

The adamantyl derivative 2a shows a first order $\mathrm{A}_{2} \mathrm{M}$-type ${ }^{31} \mathrm{P}$ NMR spectrum (considering the ${ }^{125} \mathrm{Te}$-containing isotopomer it expands to an $\mathrm{A}_{2} \mathrm{MX}$-type spectrum), consistent with an all-trans orientation of the phosphorus substituents. The P2/P4 atoms appear as a doublet at -66.6 and the $\mathrm{P} 3$ atom as a triplet at $-26.3 \mathrm{ppm}$. The ${ }^{1} J_{\mathrm{P}-\mathrm{P}}$ coupling is $169.0 \mathrm{~Hz}$; the ${ }^{l} J_{\mathrm{P}-\mathrm{Te}}$ coupling was not observed, possibly due to its surprisingly very low value of $<8 \mathrm{~Hz}$. The ${ }^{125} \mathrm{Te}$ NMR spectrum of 2a showed a doublet at $-461.1 \mathrm{ppm}\left({ }^{2} J_{\mathrm{P}-\mathrm{Te}}=80 \mathrm{~Hz}\right)$. The ${ }^{31} \mathrm{P} \mathrm{NMR}$ spectrum of $\mathbf{2 b}$ consists of a singlet ( $\mathrm{A}_{2} \mathrm{X}$ spin system) at $-79.8 \mathrm{ppm}$ accompanied by a set of tellurium satellites $\left({ }^{125} \mathrm{Te}, \mathrm{I}=1 / 2,7.1 \%\right)$, with ${ }^{l} J_{\mathrm{P}-\mathrm{Te}}=220.6 \mathrm{~Hz}$. In the ${ }^{125} \mathrm{Te}$ NMR spectrum one resonance at $-818.3 \mathrm{ppm}\left(\mathrm{t},{ }^{I} \mathrm{~J}_{\mathrm{P}-\mathrm{Te}}=218.4 \mathrm{~Hz}\right)$ is observed. The chemical shifts and coupling constants for $\mathbf{2 a}$ and $\mathbf{2 b}$ are in good agreement with the reported values of the corresponding $t$ Bu-substituted derivatives, reported by du Mont et al. ${ }^{6}$ 
A single resonance at $78.5 \mathrm{ppm}$ is observed in the ${ }^{31} \mathrm{P}$ NMR spectrum of 3a (as in $\mathbf{2 b}$ a $\mathrm{A}_{2} \mathrm{X}$ spin system), which is shifted significantly to low field compared to $\mathbf{2 b}$, presumably due to the electronegativity of the Mes*O substituent. The tellurium satellites revealed a coupling constant ${ }^{l} J_{\mathrm{P}-\mathrm{Te}}$ of $396.9 \mathrm{~Hz}$ which is quite high compared to $\mathbf{2 b}$ or the reported derivatives by du Mont et al. $(229 \mathrm{~Hz}){ }^{6}$ Tokitoh et al. $(260 \mathrm{~Hz})^{10}$ or Karaghiosoff et al. $(285.2 \mathrm{~Hz}){ }^{9}$ The observations are consistent with the triplet resonance in the ${ }^{125} \mathrm{Te}$ NMR spectrum at $7.7 \mathrm{ppm}$, which also shows a significantly low field shift when compared to the other reported $\mathrm{P}_{2}$ Te-systems and $\mathbf{2 b}$.

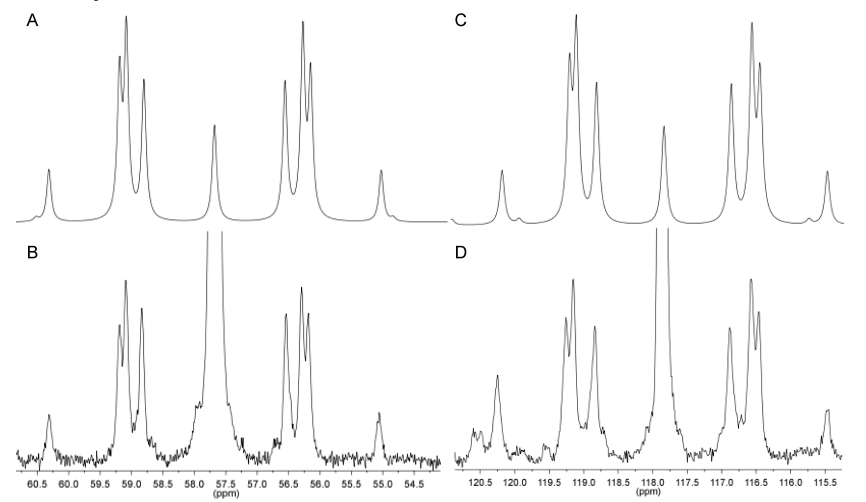

Figure 3. ${ }^{31} \mathrm{P}$ NMR spectra (109.37 MHz) of 4a (AB) and 5a (CD). (AC): A-parts of the $\mathrm{A}_{2} \mathrm{~A}^{\prime} \mathrm{X}$ spectra calculated by iterative fitting, (BD): experimental spectra.

The ${ }^{31} \mathrm{P}$ NMR spectra of $\mathbf{4 a}$ and $\mathbf{5 a}$ display singlets at $57.7 \mathrm{ppm}$ (4a) and 117.9 ppm (5a) with a characteristic pattern for the A-part of an $\mathrm{A}_{2} \mathrm{~A}^{\prime} \mathrm{X}$-spectrum, shown in Figure 3. The coupling constants were calculated by iterative fitting of the simulated spectra depicted in A, $\mathrm{C}$ of Figure 3. The ${ }^{l} J_{\mathrm{P}-\mathrm{Te}}$ values are rather large with $-441.7 \mathrm{~Hz}$ (4a) and $-398.7 \mathrm{~Hz}(\mathbf{5 a})$ respectively (negative signs are derived from iterative fitting). The ${ }^{2} J_{\mathrm{P}-\mathrm{P}}$ values were shown to be $325.0 \mathrm{~Hz}(\mathbf{4 a})$ and $257.1 \mathrm{~Hz}(\mathbf{5 a}),{ }^{3} J_{\mathrm{P}-\mathrm{Te}}$ could not be observed. The large ${ }^{2} J_{\mathrm{P}-\mathrm{P}}$ value is presumably due to a correlating alignment of the free electron pairs at the phosphorus(III) atoms, which would be consistent with a chair-like conformation of the $\mathrm{P}_{3} \mathrm{Te}_{3}$ rings with the substituents on the phosphorus atoms in equatorial positions. This was confirmed by a single crystal X-Ray structure of $\mathbf{5 a}$. The ${ }^{125} \mathrm{Te}$ NMR spectra are multiplets at 774.2 ppm (4a) and 598.9 ppm (5a) consistent with the simulation of an $\mathrm{A}_{2} \mathrm{~A}^{\prime} \mathrm{X}$ spin system (Figure 4).

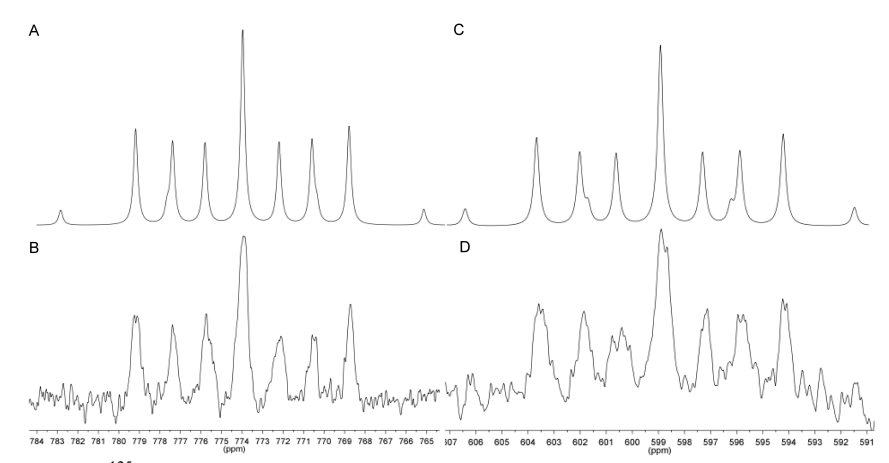

Figure 4. ${ }^{125}$ Te NMR spectra (85.24 MHz) of $4 \mathbf{a}(\mathrm{AB})$ and $5 \mathbf{a}(\mathrm{CD})$. (AC): X-part of the $\mathrm{A}_{2} \mathrm{~A}^{\prime} \mathrm{X}$ spectra calculated by iterative fitting, (BD): experimental spectra.

The ${ }^{31} \mathrm{P}$ NMR spectrum of telluratriphosphetane $\mathbf{5 b}$ shows two resonances, a doublet at $131.8 \mathrm{ppm}$ and a triplet at $82.1 \mathrm{ppm}$. In comparison to $2 \mathrm{a}$ a small ${ }^{1} J_{\mathrm{P}-\mathrm{Te}}$ coupling is visible at $72.2 \mathrm{~Hz}$, in the form of satellites at the doublet. The ${ }^{1} J_{\mathrm{P}-\mathrm{P}}$ value of $187.0 \mathrm{~Hz}$ is slightly larger than for $\mathbf{2 a}(169.0 \mathrm{~Hz})$ or the $t \mathrm{Bu}$ substituted derivative $(172.6 \mathrm{~Hz})^{6}$ but smaller than those with $\mathrm{CF}_{3}$ substituents (248.7 Hz). ${ }^{9}$

\section{X-ray structures of organophosphorus(III)-tellurium heterocycles}

Crystals of 2,3,4,5-tetra-ferrocenyl-1-tellura-2,3,4,5-tetraphospholane 1a were isolated from toluene at $-40{ }^{\circ} \mathrm{C}$ as red prisms. The crystal structure of 1a (Figure 5) reveals that the $\mathrm{P}_{4} \mathrm{Te}$ ring is non-planar with ferrocenyl groups alternating above and below the plane of the ring (all-trans conformation). The $\mathrm{P}-\mathrm{Te}$ bond length of $2.503(6) \AA$ is significantly shorter than the value of $2.565 \AA$ reported for the $\mathrm{P}^{\mathrm{III}}-\mathrm{Te}$ single bond in the acyclic compound $\mathrm{Te}(\operatorname{PiPr})_{2}{ }^{18}$, but similar to that found for a cyclic tritelluride anchored by $\mathrm{P}^{\mathrm{V}}{ }_{2} \mathrm{~N}_{2}$ rings $(d(\mathrm{P}-\mathrm{Te})=2.532-2.540(1) \AA) .{ }^{19}$ The $\mathrm{P}-\mathrm{P}$ bond lengths of $2.188(8) \AA$ and 2.163(8) $\AA$ are slightly shorter than those in the related cyclo-pentaphosphane $(\mathrm{FcP})_{5} \cdot{ }^{13}$
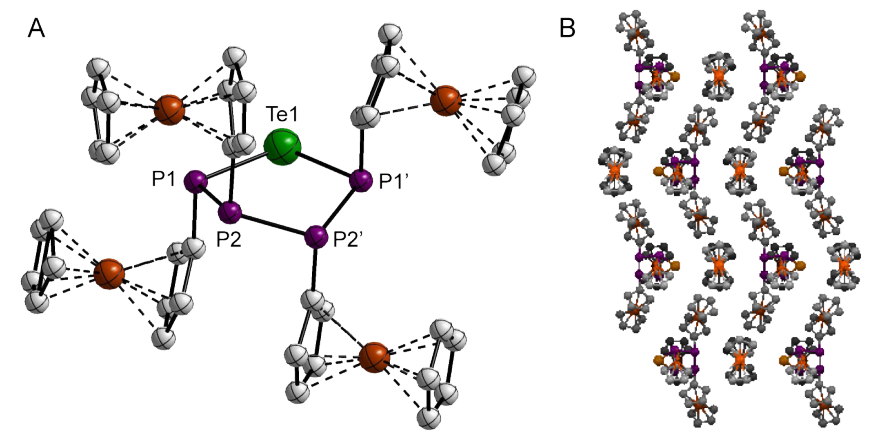

Figure 5. A: X-ray crystal structure of 1a. $\mathrm{H}$ atoms omitted for clarity. Selected bond lengths $(\AA)$ and angles $\left({ }^{\circ}\right)$ : Te1-P1 2.503(6), P1-P2 2.188(8), P2-P2' 2.163(8), P1-C1 1.84(3), P2-C11 1.83(3); P1-Te1-P1 104.89(19), Te1-P1-P2 100.9(3), Te1-P1-C1 94.7(7), P1-P2-P2' 111.2(3), P2-P1-C1 99.4(7), P2'-P2-C11 103.5(7). B: packing along the $a$-axis.

Single crystals of 2,3,4-tris-adamantyl-1-tellura-2,3,4triphosphetane 2a were isolated from THF after storing the decanted reaction mixture at $-40{ }^{\circ} \mathrm{C}$ for about two weeks (Figure 6). Two independent molecules with similar structural parameters are present in the unit cell $(Z=8)$. The $\mathrm{P}-\mathrm{Te}$ bond lengths of 2.502(2) to 2.516(2) $\AA$ are close to that found for 1a. However, the P-P bond lengths in $\mathbf{2 a}$ are slightly longer than those in the corresponding cyclo-tetraphosphane (AdP $)_{4}[d(\mathrm{P}-\mathrm{P})$ 2.2417(15)-2.2423(15) $\AA] .{ }^{20}$ The four-membered $\mathrm{P}_{3}$ Te-Ring is non-planar and the adamantyl ligands adopt an all-trans conformation (Figure 6). The ring shows a torsion angle of $161.6^{\circ}$, cf. $151.7^{\circ}$ in $(\mathrm{AdP})_{4}{ }^{20}$

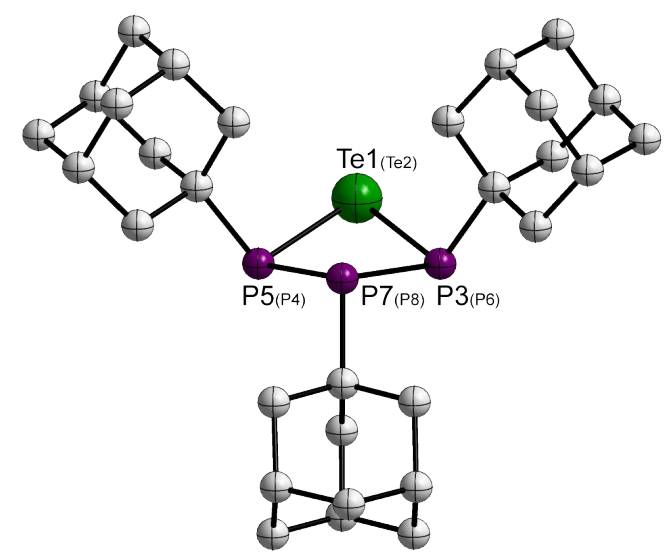

Figure 6. X-ray crystal structure of 2a. $\mathrm{H}$ atoms omitted for clarity. Two distinct molecules within the unit cell (numbering scheme for the second independent molecule in parentheses): Selected bond lengths $(\AA)$ and angles $\left({ }^{\circ}\right)$ : Te1-P3 2.502(2), Te1-P5 2.516(2), Te2-P4 2.507(2), Te2-P6 2.509(2), P3-P7 2.224(3), P4-P8 2.224(3), P5-P7 2.226(3), P6-P8 2.227(3), P3-C41 1.867(8), P4-C11 1.873(8), P5-C31 1.874(8), P6C21 1.874(8), P7-C55 1.881(8), P8-C1 1.878(8); P3-Te1-P5 80.23(7), P4-Te2-P6 80.65(7), P7-P3-Te1 90.12(9), P8-P6-Te2 89.50(9), P7-P5-Te1 89.71(9), P8-P4-Te2 89.59(9), P3-P7-P5 93.19(11), P4-P8-P6 93.64(11). 
The P-P-P-angle is at $93.19(12)^{\circ}$ the largest endocyclic angle and also demonstrates the distortion as a consequence of the $\mathrm{Te}$ incorporation when compared to the tetrakis-adamantyl-cyclotetraphosphane (P-P-P 85.58(6)-87.10(6) ${ }^{\circ}$. The P-Te-P-angle is $80^{\circ}$ and thus the smallest angle within the ring system. As for $\mathbf{1 a}$, no intermolecular $\mathrm{Te} \cdots \mathrm{Te}$ interactions are observed.

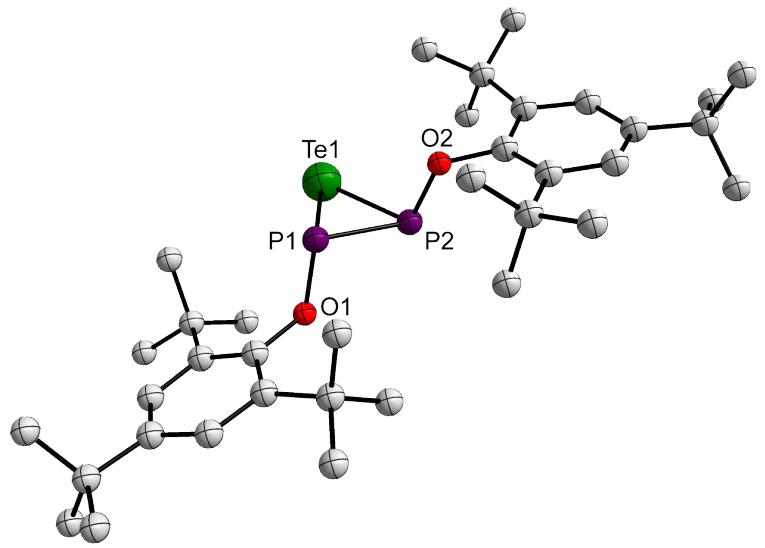

Figure 7. X-ray crystal structure of 3a. H atoms omitted for clarity. Selected bond lengths $(\AA)$ and angles $\left({ }^{\circ}\right)$ : Te1-P1 2.4794(9), Te1-P2 2.4629(10), P1-P2 2.2473(10), P1-O1 1.6639(15), P2-O2 1.6675(17); P1-Te1-P2 54.09(3), Te1-P1-P2 62.58(3), Te1-P2-P1 63.33(3), Te1-P1-O1 107.54(6), P2-P1-O1 101.36(6), Te1-P2-O2 106.42(7), P1-P2-O2 102.28(7).

Yellow crystals of 3a were isolated from a recrystallization using hexane at $-40{ }^{\circ} \mathrm{C}$. The X-Ray structure shown in Figure 7 reveals a three membered $\mathrm{P}_{2}$ Te ring system with comparatively short $\mathrm{P}-\mathrm{Te}$ distances of 2.4629(10)-2.4794(9) $\AA$ and a slightly longer P-P distance than observed in 1a and 2a. The smallest angle within the ring system is as in 2a the $\mathrm{P}-\mathrm{Te}-\mathrm{P}$ angle at 54.09(3) ${ }^{\circ}$. The Mes*O ligands on the phosphorus are in a trans position revealing a $\mathrm{O}-\mathrm{P}-$ $\mathrm{P}-\mathrm{O}$ torsion angle of $153.61^{\circ}$.

Excitingly, a recrystallization of $\mathbf{5 a}$ from THF yielded orange prisms of the first tritelluratriphosphorinane suitable for single crystal XRay analyses. The structure and selected parameters are depicted in Figure 8.

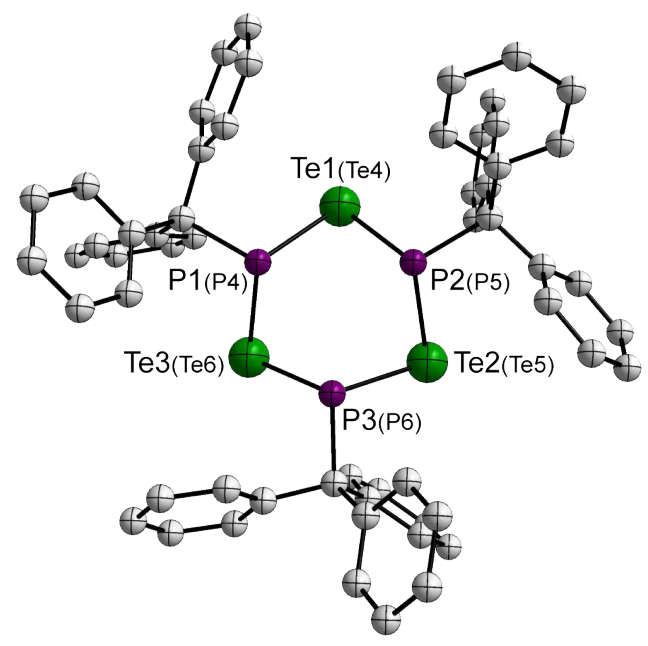

Figure 8. X-ray crystal structure of 5a. $\mathrm{H}$ atoms and solvent molecules (four per $\mathrm{P}_{3} \mathrm{Te}_{3}$ system, eight per unit cell) omitted for clarity. Two distinct molecules within the unit cell (numbering scheme for the second independent molecule in parentheses): Selected bond lengths $(\AA)$ and angles $\left({ }^{\circ}\right)$ : Te1-P1 2.502(3), Te1-P2 2.488(3), Te2-P2 2.508(3), Te2-P3 2.474(3), Te3-P1 2.482(3), Te3-P3 2.491(3), Te4-P4 2.482(3), Te4-P5 2.476(4), Te5-P5 2.492(4), Te5-P6 2.492(3), Te6-P4 2.498(3), Te6-P6 2.517(4), P-C 1.917(10)-1.938(12); P1-Te1-P2 83.41(9), P2-Te2-P3 82.52(9), P1-Te3-P3 80.94(9), P4-Te4-P5 81.80(10), P5-Te5-P6 82.51(10), P4-Te6-P6 81.70(10), Te1-P1-Te3 103.02(11), Te1-P2-Te2 104.45(11), Te2-P3-Te3 105.48(11), Te4-P4-Te6 105.67(11), Te4-P5-Te5 102.15(12), Te5-P6-Te6 102.10(12), Te-P-C 101.0(4)-105.6(4).

Two distinct molecules as well as eight THF solvent molecules are present in the unit cell. The $\mathrm{P}_{3} \mathrm{Te}_{3}$ ring crystallizes in the chair conformation, where the bulky trityl ligands are able to take the sterically advantageous equatorial positions as shown in Figure 9 A. The only structure of a heavier chalcogen $\mathrm{P}_{3}^{\mathrm{III}} \mathrm{Ch}_{3}$ system in the literature is a $\mathrm{P}_{3} \mathrm{~S}_{3}$ ring reported by Goldwhite et al.; ${ }^{21} \mathrm{P}_{3} \mathrm{Se}_{3}$ rings are unknown in the literature. The $\mathrm{P}_{3} \mathrm{~S}_{3}$ system adopts a chair conformation in contrast to the few examples of $\mathrm{P}_{3}^{\mathrm{III}} \mathrm{O}_{3}$ systems. ${ }^{22}$ The P-Te bond length of 5a range from 2.474(3) to 2.517(4) $\AA$, similar to those in the structures of 1a, 2a and 3a. The P-Te-P angles are between $80.94(9)$ and $82.52(9)^{\circ}$ and thus significantly smaller than the Te-P-Te angles $\left(102.10(12)-105.67(1)^{\circ}\right)$.
A

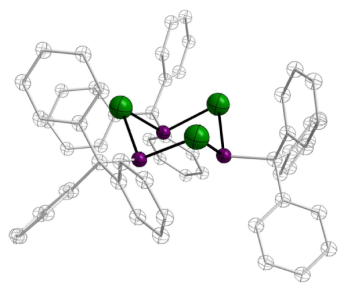

B

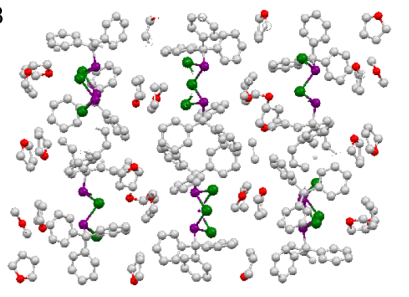

Figure 9. A) X-ray crystal structure of 5a showing the chair-like conformation and B) packing of 5a along the $a$-axis including the THF molecules (eight per unit cell). purple $=\mathrm{P}$, green $=\mathrm{Te}$, red $=\mathrm{O}$

The packing along the $a$-axis is depicted in Figure $9 \mathrm{~B}$, showing that the sterically demanding trityl substituents shield the $\mathrm{P}_{3} \mathrm{Te}_{3}$ rings from each other so that no interactions between the phosphorus(III)tellurium rings are possible.

\section{Synthesis, NMR spectra and X-ray structures of $\mathbf{P}_{2} \mathbf{N}_{2}$-stabilised organophosphorus(III)-tellurium heterocycles}

The second synthetic pathway to organophosphorus-tellurium heterocycles utilises the reaction of $\mathrm{RPCl}_{2}(\mathrm{R}=\mathrm{Ad}, t \mathrm{Bu})$ with $\left.[\mathrm{Li}(\mathrm{TMEDA})]_{2}\left[t \mathrm{BuN}(\mathrm{Te}) \mathrm{P}(\mu-\mathrm{N} t \mathrm{Bu})_{2} \mathrm{P}(\mathrm{Te}) \mathrm{N} t \mathrm{Bu}\right)\right]^{23}$ (Scheme 4 ), a dianionic reagent that has proved to be effective in the preparation of a cyclic tritelluride by metathesis with $\mathrm{TeCl}_{2} \cdot \mathrm{TMTU}^{19}$

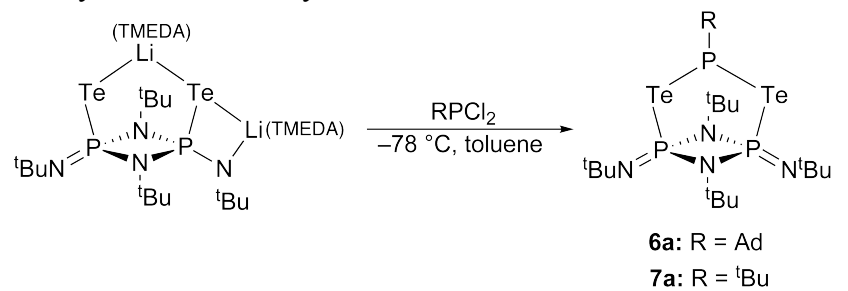

Scheme 4. Reaction of $\left.[\operatorname{Li}(\mathrm{TMEDA})]_{2}\left[t \mathrm{BuN}(\mathrm{Te}) \mathrm{P}(\mu-\mathrm{N} t \mathrm{Bu})_{2} \mathrm{P}(\mathrm{Te}) \mathrm{N} t \mathrm{Bu}\right)\right]$ with $\mathrm{AdPCl}_{2}$ and $t \mathrm{BuPCl}_{2}$ in toluene.

The reactions of $\mathrm{RPCl}_{2} \quad(\mathrm{R}=\mathrm{Ad}, t \mathrm{Bu})$ with $\left.[\mathrm{Li}(\mathrm{TMEDA})]_{2}\left[t \mathrm{BuN}(\mathrm{Te}) \mathrm{P}(\mu-\mathrm{N} t \mathrm{Bu})_{2} \mathrm{P}(\mathrm{Te}) \mathrm{N} t \mathrm{Bu}\right)\right]$ in toluene at $-78{ }^{\circ} \mathrm{C}$ produced $6 \mathbf{a}$ as orange platelets and $7 \mathbf{a}$ as orange prisms, respectively, which were identified by multinuclear NMR spectroscopy and mass spectrometry, elemental analyses and singlecrystal X-Ray analyses.

The ${ }^{31} \mathrm{P}$ NMR spectra of $6 \mathbf{a}$ and $7 \mathbf{a}$ are both characterized by a $\mathrm{A}_{2} \mathrm{M}$ spin system (with the ${ }^{125} \mathrm{Te}$-containing isotopomer it expands to an AA'MX type spectrum, where the isochronus P1 and P1' nuclei become magnetically inequivalent), showing a triplet at 89.5 (6a), $93.9 \mathrm{ppm}$, (7a) and a doublet at -129.0 (6a), $-129.6 \mathrm{ppm}$ (7a). Interestingly, the one-bond $\mathrm{P}-\mathrm{Te}$ coupling constants involving $\mathrm{P} 2$ and $\mathrm{P} 1$ differ remarkably, ${ }^{1} J_{\mathrm{P} 2-\mathrm{Te}}=420(\mathbf{6 a}), 418 \mathrm{~Hz}(\mathbf{7 a})$ and ${ }^{1} J_{\mathrm{P} 1-\mathrm{Te}}$ $=1073(\mathbf{6 a}), 1073 \mathrm{~Hz}(\mathbf{7 a})$ despite the close similarity in $\mathrm{P}-\mathrm{Te}$ bond lengths (vide infra). The disparity in ${ }^{1} J$ values is likely attributable to the difference in formal oxidation states of the two phosphorus atoms; the low value for the former is consistent with those found for $\mathrm{P}^{\mathrm{III}}-\mathrm{Te}$ compounds in this (vide supra) and previous work ${ }^{6,8,9,24}$ whereas values $>1,000 \mathrm{~Hz}$ are observed for ditelluro derivatives of the $\mathrm{P}_{2}{ }_{2} \mathrm{~N}_{2}$ ring. ${ }^{19,23,25}$ The ${ }^{125}$ Te NMR spectra displayed a doublet of 
doublets pattern centered at $368.5(\mathbf{6 a}), 423.4 \mathrm{ppm}$ (7a) with ${ }^{1} J_{\mathrm{P}-\mathrm{Te}}$ values that corroborate those found in the ${ }^{31} \mathrm{P}$ NMR spectra. The molecular structure of $\mathbf{6 a}$ (Figure 9) contains a Te- $\mathrm{P}^{\mathrm{III}}-\mathrm{Te}$ unit bridging a $\mathrm{P}_{2}{ }_{2} \mathrm{~N}_{2}$ ring cf. the derivatives $1,3-\mathrm{Te}_{2}(\mathrm{PR})_{3}\left(\mathrm{R}=t \mathrm{Bu}, \mathrm{CF}_{3}\right)$, which have been tentatively identified by NMR spectroscopy. ${ }^{7,9}$

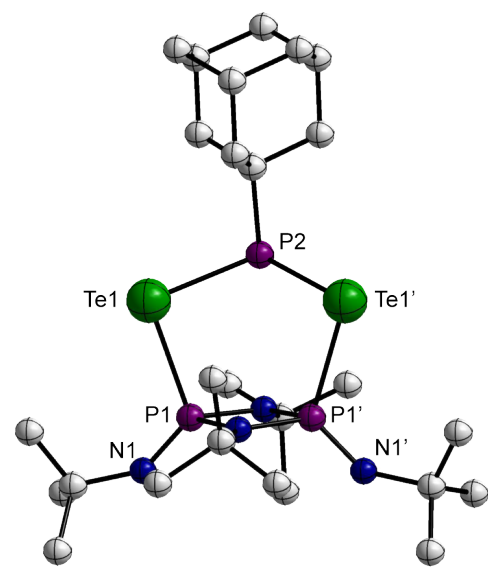

Figure 10. X-ray crystal structure of $\mathbf{6 a} . \mathrm{H}$ atoms omitted for clarity. Selected bond lengths $(\AA)$ and angles $\left(^{\circ}\right)$ : Te1-P1 2.512(3), Te1-P2 2.508(3), P1-N1 1.503(9), P1-N2 1.689(7), P1-N3 1.701(8), P2-C11 1.897(6); P1-Te1-P2 91.51(10), Te1-P1-N1 118.5(4), Te1-P1-N2 103.9(4), Te1-P1-N3 105.0(5), Te1-P2-Te1' 108.81(16), P1N2-P1' 96.5(5), P1-N3-P1' 95.6(6).

The $\mathrm{P}-\mathrm{Te}$ bond lengths $[d(\mathrm{P} 1-\mathrm{Te} 1)=2.512(3) \AA ; d(\mathrm{P} 2-\mathrm{Te} 1)=$ 2.508(3) $\AA]$ are equal within experimental error, despite the difference in oxidation states of these phosphorus atoms. The X-ray structure of $7 \mathbf{a}^{26}$ although disordered showed similar features to those described for $\mathbf{6 a}$.

\section{Conclusions}

In summary, the heterocycles 1a, 2a, 3a, 5a, 6a and 7a represent the first structurally characterized organophosphorus(III)-tellurium heterocycles. The reasonable thermal, air and light stability of these ring systems will facilitate investigations of their reactivity and coordination chemistry. In particular, the ligand behaviour of 1a, 2a, 3a and 5a can now be compared with the very limited information on metal complexes of $\mathrm{Te}\left(\mathrm{PR}_{2}\right)_{2} \cdot{ }^{27}$ From another perspective, the two Te and one $\mathrm{P}^{\mathrm{III}}$ donor atoms in $\mathbf{6 a}$ and $7 \mathbf{a}$ offer the possibility of different coordination modes compared to 1a, 2a, 3a and 5a. Compounds $4 \mathbf{a}$ and $\mathbf{5} \mathbf{a}$ are the first representatives of heterocycles of the type $\mathrm{Te}_{\mathrm{m}}(\mathrm{PR})_{\mathrm{n}}(\mathrm{m}=\mathrm{n})$ with an equal number of alternating phosphorus and tellurium atoms. Their thermal, air and light stability are significantly lower than those of the phosphorus-rich ring systems $\mathrm{Te}_{\mathrm{m}}(\mathrm{PR})_{\mathrm{n}}$ where $\mathrm{n}>\mathrm{m}$.

Although $\mathrm{Na}_{2} \mathrm{Te}_{2}$ was found to be the most effective source of tellurium in salt-elimination reactions, it is notable that no $\mathrm{P}-\mathrm{Te}$ heterocycles containing a-Te-Te- linkage were isolated or detected in solution (by NMR).

\section{Experimental section}

All synthetic manipulations were performed under an atmosphere of dry argon using standard Schlenk-line techniques and/or a Safron glovebox running with argon unless otherwise stated. All glass apparatus were stored in a drying oven $\left(120^{\circ} \mathrm{C}\right)$ and flame dried in vacuo $\left(10^{-3}\right.$ mbar) before use. Dry solvents were collected from an MBraun solvent system under a nitrogen atmosphere and stored in Schlenk flasks over $4 \AA$ molecular sieves. All chemicals were purchased from Sigma Aldrich, ABCR, Acros Organics and Strem Chemicals Inc. as long as not otherwise stated. Solution ${ }^{1} \mathrm{H}$ ${ }^{13} \mathrm{C}\left\{{ }^{1} \mathrm{H}\right\},{ }^{31} \mathrm{P}\left\{{ }_{1}^{1} \mathrm{H}\right\}$ and ${ }^{125} \mathrm{Te}\left\{{ }^{1} \mathrm{H}\right\}$ NMR spectra were recorded using a $J E O L$ DELTA EX 270, a BRUKER Avance II 400 or a BRUKER Avance III 500 spectrometer. ${ }^{1} \mathrm{H}$ and
${ }^{13} \mathrm{C}\left\{{ }^{1} \mathrm{H}\right\}$ NMR were referenced to TMS as internal standard, $85 \% \mathrm{H}_{3} \mathrm{PO}_{4}$ was used as an external standard for ${ }^{31} \mathrm{P}\left\{{ }^{1} \mathrm{H}\right\}$ NMR and $\mathrm{Ph}_{2} \mathrm{Te}$ for ${ }^{125} \mathrm{Te}\left\{{ }^{1} \mathrm{H}\right\}$ NMR spectra, all NMR data was collected at $25^{\circ} \mathrm{C}$. Mass spectrometry was performed on a MICROMASS LCT (ES) and MICROMASS GCT (EI, CI) device. Elemental analysis was performed by a CARBO ERBA CHNS analyser as long as the compounds were stable enough at RT for measurements. Melting or decomposition points were determined by sealing the sample in capillaries and heating using a Stuart SMP 30 melting point apparatus.

1a $(\mathrm{FcP})_{4} \mathrm{Te}$ : In a $100 \mathrm{~mL}$ Schlenk flask $\mathrm{Na}_{2} \mathrm{Te}_{2}{ }^{28}(525 \mathrm{mg}, 1.7 \mathrm{mmol})$ was suspended in dry THF $(10 \mathrm{~mL})$. The suspension was cooled down to $-78^{\circ} \mathrm{C}$. A solution of $\mathrm{FcPCl}_{2}$ $(500 \mathrm{mg}, 1.7 \mathrm{mmol})$ in dry THF $(10 \mathrm{~mL})$, also maintained at $-78{ }^{\circ} \mathrm{C}$, was added dropwise $(5 \mathrm{~min})$ by cannula with stirring. Stirring was continued for $3 \mathrm{~h}$ at that temperature and then at $20^{\circ} \mathrm{C}$ for another $20 \mathrm{~h}$. The reaction mixture was centrifuged and the clear yellow solution was decanted and stored for 3 days at $-20{ }^{\circ} \mathrm{C}$ under an argon atmosphere until a green precipitate was formed. The solid product was removed by filtration and washed with THF. The residue was heated in boiling toluene for $2 \mathrm{~h}$, and the solution was filtered hot (to remove $(\mathrm{FcP})_{5}$ ) and stored at $-20{ }^{\circ} \mathrm{C}$ overnight to yield 2,3,4,5-tetra-ferrocenyl-1-tellura-2,3,4,5-tetraphospholane as red crystals (yield: $9 \%) .{ }^{31} \mathrm{P}$ NMR $\left(\left[\mathrm{D}_{8}\right] \mathrm{THF}\right): \delta=84.5\left(\mathrm{~m},{ }^{1} \mathrm{~J}\left(\mathrm{P}_{1}, \mathrm{P}_{2}\right)=-305.1 \mathrm{~Hz} ;{ }^{2} \mathrm{~J}\left(\mathrm{P}_{1}, \mathrm{P}_{2}{ }^{\prime} / \mathrm{P}_{1}{ }^{\prime}, \mathrm{P}_{2}\right)=\right.$ $\left.31.0 \mathrm{~Hz},{ }^{2} \mathrm{~J}\left(\mathrm{P}_{1}, \mathrm{P}_{1}{ }^{\prime}\right)=12.0 \mathrm{~Hz}\right), 69.6\left(\mathrm{~m},{ }^{1} \mathrm{~J}\left(\mathrm{P}_{1}, \mathrm{P}_{2}\right)=-305.1 \mathrm{~Hz} ;{ }^{1} \mathrm{~J}\left(\mathrm{P}_{2}, \mathrm{P}_{2},\right)=-339.0 \mathrm{~Hz}\right.$, $\left.{ }^{2} \mathrm{~J}\left(\mathrm{P}_{1}, \mathrm{P}_{2}{ }^{\prime} / \mathrm{P}_{1}{ }^{\prime}, \mathrm{P}_{2}\right)=31.0 \mathrm{~Hz}\right) \mathrm{ppm} .{ }^{125} \mathrm{Te} \mathrm{NMR}\left(\left[\mathrm{D}_{8}\right] \mathrm{THF}\right): \delta=$ no sharp signals due to low solubility. M.p. $>200^{\circ} \mathrm{C}$. MS $[\mathrm{CI}+, \mathrm{m} / \mathrm{z}], 992.9[\mathrm{M}+\mathrm{H}]^{+}$(calculated: 992.8 $[\mathrm{M}+\mathrm{H}]^{+}$); HR-MS [APCI(ASAP, m/z], $994.8303[\mathrm{M}+\mathrm{H}]^{+}$(calculated: 994.8304 $[\mathrm{M}+\mathrm{H}]^{+}$); EA calcd (\%) for $\mathrm{C}_{40} \mathrm{H}_{36} \mathrm{P}_{4} \mathrm{TeFe}_{4}$ : C 48.45, H 3.66, found: C 48.35, H 3.73.

2a $(\mathrm{AdP})_{3} \mathrm{Te}$ and $\mathbf{2 b}(\mathrm{AdP})_{2} \mathrm{Te}$ : Procedure as for 1a using $\mathrm{AdPCl}_{2}{ }^{29}(500 \mathrm{mg}, 2.1 \mathrm{mmol})$ and $\mathrm{Na}_{2} \mathrm{Te}_{2}(633 \mathrm{mg}, 2.1 \mathrm{mmol})$. After the clear red solution had been decanted it was concentrated and stored at $-40{ }^{\circ} \mathrm{C}$. After 14 days crystals of 2a appeared, which were filtered off and dried under vacuum (yield: $<5 \%$ ). The solvent was removed from the filtrate and the solid material washed with cold pentane to give $\mathbf{2 b}$ (yield $36 \%$ ).

2a: ${ }^{31} \mathrm{P}$ NMR ([D $]$ THF): $\delta=-66.6\left({ }^{1} J(\mathrm{P}, \mathrm{P})=166.7 \mathrm{~Hz}\right),-26.3\left({ }^{1} J(\mathrm{P}, \mathrm{P})=166.7 \mathrm{~Hz}\right)$ ppm. ${ }^{125} \mathrm{Te}$ NMR ([D 8$\left.] \mathrm{THF}\right): \delta=-461.1\left({ }^{1} J(\mathrm{P}, \mathrm{Te})=<8 \mathrm{~Hz},{ }^{2} J(\mathrm{P}, \mathrm{Te})=80 \mathrm{~Hz}\right) \mathrm{ppm}$. MS $\left(\mathrm{EI}^{+}, \mathrm{m} / \mathrm{z}\right), 628.2[\mathrm{M}]^{+}$(calculated: $\left.628.2[\mathrm{M}]^{+}\right)$. HR-MS $\left(\mathrm{EI}^{+}, \mathrm{m} / \mathrm{z}\right) 620.1752[\mathrm{M}]^{+}$, (calculated: $\left.620.1759[M]^{+}=\mathrm{C}_{30} \mathrm{H}_{45} \mathrm{P}_{3}{ }^{122} \mathrm{Te}_{1}\right) .2 \mathrm{~b}:{ }^{31} \mathrm{P}$ NMR ([D $\left.\left.\mathrm{D}_{8}\right] \mathrm{THF}\right): \delta=-79.8(\mathrm{~s}$, $\left.{ }^{1} J(\mathrm{P}, \mathrm{Te})=220.6 \mathrm{~Hz}\right) \mathrm{ppm} .{ }^{125} \mathrm{Te} \mathrm{NMR}\left(\left[\mathrm{D}_{8}\right] \mathrm{THF}\right): \delta=-818.3\left(\mathrm{~s},{ }^{1} J(\mathrm{P}, \mathrm{Te})=218.4 \mathrm{~Hz}\right)$ ppm. M.p. $>114{ }^{\circ} \mathrm{C}(\mathrm{dec})$. MS $\left(\mathrm{EI}^{+}, \mathrm{m} / \mathrm{z}\right), 462.0[\mathrm{M}]^{+}$(calculated: $\left.462.1[M]^{+}\right)$.

3a (Mes*OP) $)_{2} \mathrm{Te}$ : Procedure as for 1a using $\mathrm{Mes}^{*} \mathrm{OPCl}_{2}{ }^{30}(500 \mathrm{mg}, 1.4 \mathrm{mmol})$ and $\mathrm{Na}_{2} \mathrm{Te}_{2}(415 \mathrm{mg}, 1.4 \mathrm{mmol})$. After the $20 \mathrm{~h}$ of stirring at RT the THF was removed and $25 \mathrm{~mL}$ of hexane added. The suspension was stirred for $30 \mathrm{~min}$, filtered and the filtrate concentrated to about $8 \mathrm{~mL}$. The yellow solution was stored at $-40{ }^{\circ} \mathrm{C}$, to afford yellow crystals after three days. The crystals were filtered off and dried under vacuum, the filtrate again concentrated and left at $-40{ }^{\circ} \mathrm{C}$ for a second batch of crystals. The yellow material was dried under vacuum for $3 \mathrm{~h}$ resulting in an overall yield of $37 \%$.

${ }^{1} \mathrm{H}$ NMR $\left(\left[\mathrm{D}_{8}\right] \mathrm{THF}\right): \delta=7.31(\mathrm{~s}, 2 \mathrm{H}), 1.50(\mathrm{~s}, 18 \mathrm{H}), 1.33(\mathrm{~s}, 9 \mathrm{H}) \mathrm{ppm} .{ }^{31} \mathrm{P}$ NMR ([D $\left.\left.\mathrm{D}_{8}\right] \mathrm{THF}\right): \delta=78.5\left(\mathrm{~s},{ }^{1} J\left(\mathrm{P},{ }^{125} \mathrm{Te}\right)=396.9 \mathrm{~Hz},{ }^{1} J\left(\mathrm{P},{ }^{123} \mathrm{Te}\right)=332.1 \mathrm{~Hz}\right) \mathrm{ppm} .{ }^{125} \mathrm{Te}$ NMR $\left(\left[\mathrm{D}_{8}\right] \mathrm{THF}\right): \delta=7.7\left(\mathrm{t},{ }^{1} J\left(\mathrm{P},{ }^{125} \mathrm{Te}\right)=394.6 \mathrm{~Hz}\right) \mathrm{ppm} . \mathrm{M} . \mathrm{p} .>126^{\circ} \mathrm{C}(\mathrm{dec}) . \mathrm{MS}\left(\mathrm{EI}^{+}, m / z\right)$, 453.0 $\left[\mathrm{M}-\mathrm{OMes}^{*}\right]^{+}$(calculated: $\left.453.1\left[\mathrm{M}-\mathrm{OMes}^{*}\right]^{+}\right) ; 601.1[\mathrm{M}-2 \mathrm{tBu}+\mathrm{H}]^{+}$(calculated: $\left.601.2[\mathrm{M}-2 \mathrm{tBu}+H]^{+}\right) ; 262.2\left[\mathrm{OMes}^{*+H}\right]^{+}$(calculated: $\left.262.2\left[\mathrm{OMes}^{*+H}\right]^{+}\right)$; EA calcd (\%) for $\mathrm{C}_{36} \mathrm{H}_{58} \mathrm{O}_{2} \mathrm{P}_{2}$ Te: $\mathrm{C} 60.69, \mathrm{H} 8.21$, found: $\mathrm{C} 60.72, \mathrm{H} 8.13$.

4a $(\text { Mes*P })_{3} \mathrm{Te}_{3}$ : Procedure as for 1a using $\mathrm{Mes}^{*} \mathrm{PCl}_{2}{ }^{31}(500 \mathrm{mg}, 1.4 \mathrm{mmol})$ and $\mathrm{Na}_{2} \mathrm{Te}_{2}$ (434 mg, $1.4 \mathrm{mmol}$ ). After the clear yellow solution had been decanted the solvent was removed. The mixture was dissolved in hexane and filtered, followed by a removal of the hexane. The analysed mixture mainly contains Mes*P=PMes* $(55 \%)$ and $4 \mathrm{a}(40 \%)$. A recrystallization from hexane afforded orange crystals of Mes* $\mathrm{P}=\mathrm{PMes} *$, the main decomposition product of $\mathbf{4 a}$.

${ }^{31} \mathrm{P}$ NMR ([D 8 THF $): \delta=57.7\left(\mathrm{~s},{ }^{1} J\left(\mathrm{P},{ }^{125} \mathrm{Te}\right)=-441.7,{ }^{2} J(\mathrm{P}, \mathrm{P})=325.0 \mathrm{~Hz}\right) \cdot{ }^{125} \mathrm{Te} \mathrm{NMR}$ $\left(\left[\mathrm{D}_{8}\right] \mathrm{THF}\right): \delta=774.2\left(\mathrm{~m},{ }^{1} J\left(\mathrm{P},{ }^{125} \mathrm{Te}\right)=442.0 \mathrm{~Hz}\right) \mathrm{ppm}$. MS $\left(\mathrm{EI}^{+}, \mathrm{m} / \mathrm{z}\right)$ : only fragments observed: $277.1\left[\text { PMes }^{*}+H\right]^{+}$(calculated: $277.2\left[\mathrm{M}^{+}\right.$).

5a $(\operatorname{TrtP})_{3} \mathrm{Te}_{3}$ and $\mathbf{5 b}(\mathrm{TrtP})_{3} \mathrm{Te}$ : Procedure as for 1a using $\operatorname{TrtPCl}_{2}{ }^{32}(500 \mathrm{mg}, 1.5 \mathrm{mmol})$ and $\mathrm{Na}_{2} \mathrm{Te}_{2}(436 \mathrm{mg}, 1.5 \mathrm{mmol})$. After the clear red solution had been decanted the solvent was removed. Recrystallization from THF at $-40{ }^{\circ} \mathrm{C}$ afforded orange crystals of $(\mathrm{TrtPTe})_{3}$ in an overall yield of $8 \%$.

5a: ${ }^{31} \mathrm{P}$ NMR $\left(\left[\mathrm{D}_{8}\right] \mathrm{THF}\right): \delta=117.9\left(\mathrm{~s},{ }^{1} J\left(\mathrm{P},{ }^{125} \mathrm{Te}\right)=-398.7,{ }^{2} J(\mathrm{P}, \mathrm{P})=257.1 \mathrm{~Hz}\right) .{ }^{125} \mathrm{Te}$ NMR $\left(\left[\mathrm{D}_{8}\right] \mathrm{THF}\right): \delta=598.9\left(\mathrm{~m},{ }^{1} J\left(\mathrm{P},{ }^{125} \mathrm{Te}\right) 396.3 \mathrm{~Hz}\right) \mathrm{ppm}$. MS $\left(\mathrm{EI}^{+}, \mathrm{m} / \mathrm{z}\right)$ : only fragments observed: $243.1[\operatorname{Trt}]^{+}$(calculated: $\left.243.1[\operatorname{Trt}]^{+}\right), \mathrm{Te}_{\mathrm{n}}(\mathrm{n}=2,3,4,5,6)$. EA calcd (\%) for $\mathrm{C}_{73} \mathrm{H}_{77} \mathrm{O}_{4} \mathrm{P}_{3} \mathrm{Te}_{3}(\mathbf{5 a}+4$ THF): C 58.69, H 5.19, found: C 58.51, H 4.98. 5b: ${ }^{31} \mathrm{P}$ NMR $\left(\left[\mathrm{D}_{8}\right] \mathrm{THF}\right): \delta=131.8\left(\mathrm{~d},{ }^{1} J\left(\mathrm{P},{ }^{125} \mathrm{Te}\right)=72.2 \mathrm{~Hz},{ }^{1} J(\mathrm{P}, \mathrm{P})=189.2 \mathrm{~Hz},{ }^{2} J(\mathrm{P}, \mathrm{P})\right.$ $=3.3 \mathrm{~Hz}), 82.1\left(\mathrm{t},{ }^{1} J(\mathrm{P}, \mathrm{P})=187.0 \mathrm{~Hz}\right) \mathrm{ppm} .{ }^{125} \mathrm{Te}$ NMR $\left(\left[\mathrm{D}_{8}\right] \mathrm{THF}\right)$ : due to the low yield

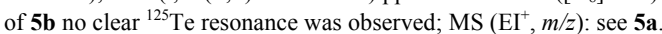

6a $\left.\left[{ }^{t} \mathrm{BuN}\right) \mathrm{P}\left(\mu-\mathrm{N}^{t} \mathrm{Bu}\right)_{2} \mathrm{P}\left(\mathrm{N}^{t} \mathrm{Bu}\right)(\mu-\mathrm{Te}-\mathrm{P}(\mathrm{Ad})-\mathrm{Te})\right]$ :

[Li(TMEDA) $\left.]_{2}\left[t \mathrm{BuN}(\mathrm{Te}) \mathrm{P}(\mu-\mathrm{N} t \mathrm{Bu})_{2} \mathrm{P}(\mathrm{Te}) \mathrm{N} t \mathrm{Bu}\right)\right](500 \mathrm{mg}, 0.59 \mathrm{mmol})$ was suspended in toluene $(10 \mathrm{~mL})$ and cooled to $-78{ }^{\circ} \mathrm{C}$. $\mathrm{AdPCl}_{2}(140 \mathrm{mg}, 0.59 \mathrm{mmol})$ was dissolved in toluene $(10 \mathrm{~mL})$, maintained at $-78{ }^{\circ} \mathrm{C}$ and then added dropwise to the solution of $\left.[\mathrm{Li}(\mathrm{TMEDA})]_{2}\left[t \mathrm{BuN}(\mathrm{Te}) \mathrm{P}(\mu-\mathrm{N} t \mathrm{Bu})_{2} \mathrm{P}(\mathrm{Te}) \mathrm{N} t \mathrm{Bu}\right)\right]$ over 15 min by cannula. The reaction mixture was stirred at that temperature for $2 \mathrm{~h}$ and then warmed to room temperature. After stirring for an additional $1 \mathrm{~h}$, the precipitate $(\mathrm{LiCl})$ was filtered off and the solvent 
removed under vacuum. The obtained solid was dissolved in hexane and maintained at $-40{ }^{\circ} \mathrm{C}$ overnight. The deep red crystals were filtered off and dried under vacuum. The resulting filtrate was concentrated and again placed in the freezer overnight to produce another batch of crystals (overall yield: $23 \%) .{ }^{1} \mathrm{H}$ NMR $\left(\mathrm{C}_{6} \mathrm{D}_{6}\right): \delta=1.98(\mathrm{~m}, 9 \mathrm{H}, \mathrm{Ad})$ $1.82\left(\mathrm{~s}, 9 \mathrm{H},{ }^{\mathrm{t}} \mathrm{Bu}\right), 1.73\left(\mathrm{~s}, 9 \mathrm{H},{ }^{\mathrm{t}} \mathrm{Bu}\right), 1.47\left(\mathrm{~s}, 18 \mathrm{H},{ }^{\mathrm{t}} \mathrm{Bu}\right), 1.42(\mathrm{~m}, 6 \mathrm{H}, \mathrm{Ad}) \mathrm{ppm} .{ }^{31} \mathrm{P}$ NMR $\left(\mathrm{C}_{6} \mathrm{D}_{6}\right): \delta=89.5\left(\mathrm{t},{ }^{1} J(\mathrm{P}, \mathrm{Te})=420 \mathrm{~Hz},{ }^{2} J(\mathrm{P}, \mathrm{P})=8.1 \mathrm{~Hz}\right),-129.0\left(\mathrm{~d},{ }^{1} J(\mathrm{P} 1, \mathrm{Te})=\right.$ $\left.1073 \mathrm{~Hz},{ }^{2} J(\mathrm{P} 1, \mathrm{P} 2)=8.1 \mathrm{~Hz},{ }^{2} J\left(\mathrm{P} 1, \mathrm{P} 1{ }^{\prime}\right)=21 \mathrm{~Hz}\right) \mathrm{ppm} .{ }^{125} \mathrm{Te}$ NMR $\left(\left[\mathrm{D}_{8}\right]\right.$ toluene $): \delta=$ $368.5\left({ }^{1} J(\mathrm{P} 2, \mathrm{Te})=418 \mathrm{~Hz},{ }^{1} J(\mathrm{P} 1, \mathrm{Te})=1073 \mathrm{~Hz},{ }^{3} J(\mathrm{P}, \mathrm{Te})=29 \mathrm{~Hz}\right) \mathrm{ppm} . \mathrm{MS}\left(\mathrm{CI}^{+}, m / z\right)$ $769.1[M+\mathrm{H}]^{+}$(calculated: $769.1[M+\mathrm{H}]^{+}$); EA calcd (\%) for $\mathrm{C}_{26} \mathrm{H}_{51} \mathrm{~N}_{4} \mathrm{P}_{3} \mathrm{Te}_{2}: \mathrm{C} 40.67, \mathrm{H}$ 6.69 , N 7.30, found: C 40.76, H 6.71, N 7.38

7a $\left.\left[{ }^{t} \mathrm{BuN}\right) \mathrm{P}\left(\mu-\mathrm{N}^{t} \mathrm{Bu}\right)_{2} \mathrm{P}\left(\mathrm{N}^{t} \mathrm{Bu}\right)(\mu-\mathrm{Te}-\mathrm{P}(t \mathrm{Bu})-\mathrm{Te})\right]:$

Procedure as for 6a using $t \mathrm{BuPCl}_{2} \quad(94 \quad \mathrm{mg}, \quad 0.59 \mathrm{mmol})$ and $\left.[\mathrm{Li}(\mathrm{TMEDA})]_{2}\left[t \mathrm{BuN}(\mathrm{Te}) \mathrm{P}(\mu-\mathrm{N} t \mathrm{Bu})_{2} \mathrm{P}(\mathrm{Te}) \mathrm{N} t \mathrm{Bu}\right)\right] \quad(500 \mathrm{mg}, \quad 0.59 \mathrm{mmol}) \quad$ (Yield $18 \%) .{ }^{1} \mathrm{H}$ NMR ([D $\left.\mathrm{D}_{8}\right]$ toluene): $\delta=1.86\left(\mathrm{~s}, 9 \mathrm{H},{ }^{\mathrm{t}} \mathrm{Bu}\right), 1.72\left(\mathrm{~s}, 9 \mathrm{H},{ }^{\mathrm{t}} \mathrm{Bu}\right), 1.45\left(\mathrm{~s}, 18 \mathrm{H},{ }^{\mathrm{t}} \mathrm{Bu}\right)$ $1.40\left(\mathrm{~d}, 9 \mathrm{H}, \mathrm{P}{ }^{\mathrm{t}} \mathrm{Bu},{ }^{2} J(\mathrm{P}, \mathrm{H})=12 \mathrm{~Hz}\right) \mathrm{ppm} .{ }^{31} \mathrm{P}$ NMR $\left(\left[\mathrm{D}_{8}\right]\right.$ toluene $): \delta=93.9\left(\mathrm{t},{ }^{1} J(\mathrm{P}, \mathrm{Te})\right.$ $\left.=418 \mathrm{~Hz},{ }^{2} J(\mathrm{P} 2, \mathrm{P} 1)=8.1 \mathrm{~Hz}\right),-129.6\left(\mathrm{~d},{ }^{1} J(\mathrm{P}, \mathrm{Te})=1073 \mathrm{~Hz},{ }^{2} J(\mathrm{P} 1, \mathrm{P} 2)=8.4 \mathrm{~Hz}\right.$, $\left.{ }^{2} J\left(\mathrm{P} 1, \mathrm{P} 1{ }^{\prime}\right)=21 \mathrm{~Hz}\right) \mathrm{ppm} \cdot{ }^{125} \mathrm{Te}$ NMR $\left(\left[\mathrm{D}_{8}\right]\right.$ toluene $): \delta=423.4\left({ }^{1} J(\mathrm{P} 2, \mathrm{Te})=416 \mathrm{~Hz}\right.$, $\left.{ }^{1} J(\mathrm{P} 1, \mathrm{Te})=1073 \mathrm{~Hz},{ }^{3} J(\mathrm{P}, \mathrm{Te})=32 \mathrm{~Hz}\right) \mathrm{ppm} . \mathrm{MS}\left(\mathrm{CI}^{+}, m / z\right), 691.1[M+\mathrm{H}]^{+}$(calculated $\left.691.1[M+\mathrm{H}]^{+}\right)$; EA: calcd (\%) for $\mathrm{C}_{20} \mathrm{H}_{45} \mathrm{~N}_{4} \mathrm{P}_{3} \mathrm{Te}_{2}$ : C 34.83, H 6.58, N 8.12, found: $\mathrm{C}$ 34.84, H 6.61, N 7.97 .

X-ray crystal data for compounds $1 \mathbf{a}, \mathbf{3 a}, \mathbf{5 a}, \mathbf{6 a}$ and $7 \mathbf{a}$ were collected by a Rigaku Mo MM007 (dual port) high brilliance generator with Saturn 70 and Mercury CCD detectors, rotating anode/confocal optics and two XStream LT accessories at $-180(1){ }^{\circ} \mathrm{C}$. 2a was measured on a Nonius-KappaCCD, equipped with rotating anode at $-73{ }^{\circ} \mathrm{C}$. All data were collected with graphite-monochromated Mo-K $\alpha$ radiation $(\lambda=0.71073 \AA)$ and corrected for Lorentz and polarization effects

These data can be obtained free of charge via www.ccdc.cam.ac.uk/conts/retrieving.html or from the Cambridge Crystallographic Data centre, 12 Union Road, Cambridge CB2 1EZ, UK; fax (+44) 1223-336-033; email: deposit@.ccdc.cam.ac.uk. CCDC nos 1a 945396, 2a 945397, 3a 961072, 5a 961073, 6a 945398, 7a 945400, (AdP) 4945399

\section{Acknowledgements}

We are grateful to the University of St Andrews, the EPSRC and NSERC Canada for their financial support.

[1] H. Hoffman, G. Schumacher, Tetrahedron Lett. 1967, 8, 2963-2966.

[2] a) G. Hua, J. D. Woollins, Angew. Chem. 2009, 121, 1394-1403; Angew. Chem. Int. Ed. 2009, 48, 1368-1377; b) G. Hua, J. M. Griffin, S. E. Ashbrook, A. M. Z Slawin and J. D. Woollins, Angew. Chem. Int. Ed. Engl., 2011, 50, $4123-4126$; c) G. Hua, A. M. Z. Slawin, R. A. M. Randall, D. B. Cordes, L. Crawford, M Bühl and J. D. Woollins, Chem.Commun, 2013, 2619-2621; d) J. D. Woollins, Synlett, 2012, 23, 1154-1169.

[3] M. Jesberger, T. P. Davis, Synthesis 2003, 13, 1929-1958

[4] a) Topics in Current Chemistry: Organoselenium Chemistry, Modern Developments in Organic Synthesis; T. Wirth, Ed.; Springer: Berlin, Germany, 2000; b) T. Wirth, Angew. Chem. 2000, 112, 3890-3900; Angew. Chem., Int. Ed. 2000, 39, 3740-3749.

[5] T. Chivers, I. Manners, "Inorganic Rings and Polymers of the p-Block Elements: From Fundamentals to Applications", RSC Publishing, Cambridge, UK, 2009, pp. 256-260.

[6] W.-W. du Mont, T. Severengiz, B. Meyer, Angew. Chem. 1983, 95, 1025-1026; Angew. Chem. Int. Ed. Engl. 1983, 22, 983-984.

[7] W.-W. du Mont, T. Severengiz, Z. Anorg. Allg. Chem. 1993, 619, 1083-1087.

[8] S. Grimm, K. Karaghiosoff, P. Mayer, D. Ross, Phosphorus Sulfur Silicon 2001,169, 51-54

[9] K. Lux, O. Schön, K. Karaghiosoff, Z. Anorg. Allg. Chem. 2009, 635, 24652469.

[10] N. Nagahora, T. Sasamori, N. Tokitoh, Heteroatom. Chem. 2008, 19, (5), 443449.

[11] The higher thermal robustness of the adamantyl (Ad) compared to the $t \mathrm{Bu}$ derivative enabled the first structural characterization of a selenium diimide, $\mathrm{RN}=\mathrm{Se}=\mathrm{NR}$. a) T. Maaninen, R. Laitinen, T. Chivers. Chem. Commun. 2002,
2332-2333; For examples of FcLR chemistry see b) M. R. StJ. Foreman, A. M. Z. Slawin, J. D.Woollins, J. Chem. Soc., Chem.Commun. 1997, 855-856; c) M. StJ. Foreman, J. D. Woollins, J. Chem. Soc. Dalton, 2000, 1533-1543.

[12] J. R. Goerlich, J. V. Weiss, P. G. Jones, R. Schmutzler, Phosphorus, Sulfur Silicon Relat. Elem. 1992, 66, 223-243.

[13] V. Naseri, R. J. Lessa, R. E. Mulvey, M. McPartlin, D. S. Wright, Chem. Commun. 2010, 46, 5000-5002.

[14] At low temperature resonances in the ${ }^{31} \mathrm{P}$ NMR spectrum were observed which indicate the presence of a 1,3-ditellura-2,4,5-triphospholane consistent with an ABM spectrum (ignoring the ${ }^{125} \mathrm{Te}$-containing isotopomers). At room temperature the signals disappear, which precluded further characterization. The spin simulation and spectrum of the compound are displayed in the supplementary information. The calculated values of the NMR parameters are comparable to those of du Mont's $(t \mathrm{BuP})_{3} \mathrm{Te}_{2}{ }^{7}$ A reinvestigation of $(t \mathrm{BuP})_{3} \mathrm{Te}_{2}$ showed three distinct phosphorus signals in the ${ }^{31} \mathrm{P}$ NMR consistent with the suggested cis-structure. ${ }^{7}$ Similarly, Karaghiosoff reported $\left(\mathrm{CF}_{3} \mathrm{P}\right)_{3} \mathrm{Te}_{2}{ }^{.}$

[15] M. Yoshifuji, I. Shima, N. Inamoto, J. Am. Chem. Soc. 1981, 103, 4587-4589.

[16] All spin simulations were performed by using MestReNova v7.1.1.

[17] The negative signs of the coupling constants result from the iterative fitting of the spectrum.

[18] H. Westermann, M. Nieger, E, Niecke, Chem. Ber. 1991, 124, 13-16.

[19] A. Nordheider, T. Chivers, R. Thirumoorthi, K. S. Athukorala, A. M. Z. Slawin, J. D. Woollins. I. Vargas-Baca, Dalton Trans. 2013, 42, 3291-3294.

[20] J. R. Goerlich, R. Schmutzler, Z. Anorg. Allg. Chem. 1994, 620, 173-6; the XRay structure of tetrakis-adamantyl-cyclo-tetraphosphane can be found in the ESI. Yellow crystals of $(\mathrm{AdP})_{4}$ were isolated when an excess of $\mathrm{Na}_{2} \mathrm{Te}_{2}$ was used in the reaction with $\mathrm{AdPCl}_{2}$

[21] B. Cetinkaya, P. B. Hitchcock, M. F. Lappert, A. J. Thorne, H. Goldwhite, J. Chem. Soc. Chem. Comm. 1982, 691-693.

[22] $\left(\mathrm{OPNPr}_{2}^{\prime}\right)_{3}$ adopts a boat conformation, a) E. Niecke, H. Zorn, B. Krebs, G Henkel, Angew. Chem. Int. Ed. Engl. 1980, 19, 709-710. [OP $\left(\mathrm{O}(o-t \mathrm{Bu})_{2} p-\right.$ $\left.\left.\mathrm{Me}) \mathrm{C}_{6} \mathrm{H}_{2}\right)\right]_{3}$ was observed in a twisted boat conformation, b) D. W. Chasar, J. P. Fackler, A. M. Mazany, R. A. Komoroski, W. J. Kroenke, J. Am. Chem. Soc. 1986, $108,5956-35962$.

[23] G. G. Briand, T. Chivers, M. Parvez, Angew. Chem. 2002, 114, 3618-3620; Angew. Chem., Int. Ed. 2002, 41, 3468-3470.

[24] R. P. Davies, M. G. Martinelli, A. E. H. Wheatley, A. J. P. White, D. J. Williams, Eur. J. Inorg. Chem. 2003, 3409-3416.

[25] G. G. Briand, T. Chivers, M. Parvez, G. Schatte, Inorg. Chem. 2003, 42, 525531.

[26] The disordered structure and crystallographic data including bond distances and angles for $\mathbf{7 a}$ are deposited in the supplementary information.

[27] Investigations of the coordination chemistry of acyclic $\mathrm{Te}\left(\mathrm{PR}_{2}\right)_{2}$ ligands have been limited to the $P, P^{\prime}$-chelated complex $\mathrm{Cr}(\mathrm{CO})_{4}\left[\mathrm{Te}(\mathrm{P} t \mathrm{Bu})_{2}\right)_{2}$. R. Hensel, WW. du Mont, R. Boese, D. Wewers, L. Weber, Chem. Ber. 1985, 118, 15801587.

[28] $\mathrm{Na}_{2} \mathrm{Te}_{2}$ was synthesized similarly to the literature procedure: C. A. Kraus, C. Y. Chiu, J. Am. Chem. Soc. 1922, 44, 1999-2008. The details of the experimental procedure can be found in the supporting information.

[29] A new synthesis was developed, which can be found in the Supporting Information. It was based on the literature procedure M. Gouygou, G. EtemadMoghadam, M. Koenig, Synthesis 1987, 508-510, but offers several advantages.

[30] H. Lang, M. Leise, L. Zsolnai, J. Organomet. Chem. 1990, 386, 349-363.

[31] a) M. Yoshifuji, Synthetic Methods of Organometallic and Inorganic Chemistry 1996, 3, 118-125, b) M. Yoshifuji, I. Shima, N. Inamoto, J. Am. Chem. Soc. 1981, 103, 4587-4589.

[32] V. Plack, J. R. Goerlich, A. Fischer, H. Thönnessen, P.G. Jones, R. Schmutzler, Z. Anorg. Allg. Chem. 1995, 621, 1080-1092.

Received: ((will be filled in by the editorial staff))

Revised: ((will be filled in by the editorial staff)) Published online: ((will be filled in by the editorial staff)) 


\section{Entry for the Table of Contents}

Layout 2:

Isolatable

organophosphorus(III)-

tellurium heterocycles

Andreas Nordheider, Tristram

Chivers, Oliver Schön, Konstantin

Karaghiosoff, Kasun S Athukorala

Arachchige, Alexandra M. Z.

Slawin and J. Derek Woollins*

Page - Page

\section{Isolatable}

organophosphorus(III)-

tellurium heterocycles

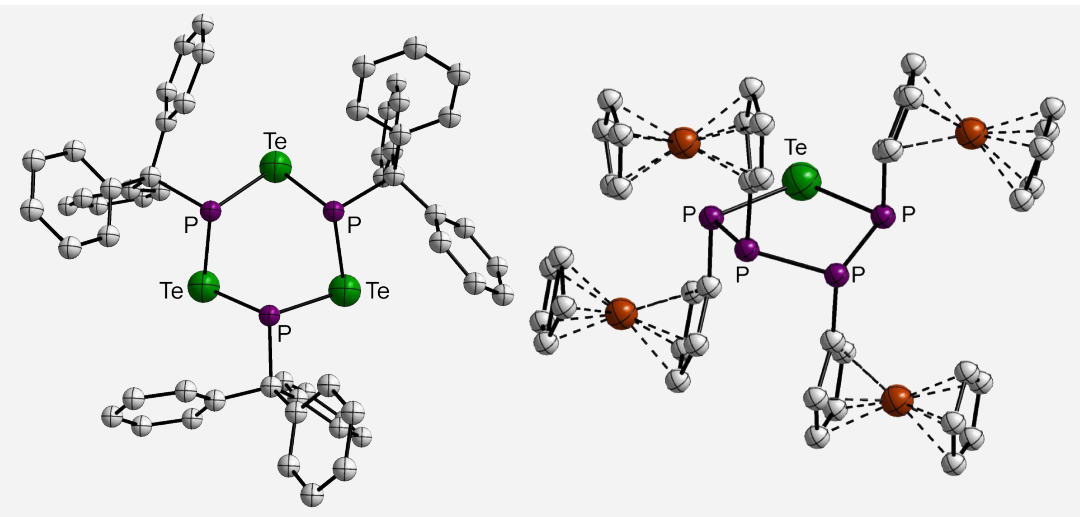

Organophosphorus(III)-tellurium

or (b) the installation of a $\mathrm{P}_{2}{ }_{2} \mathrm{~N}_{2}$ heterocycles can be stabilized and structurally characterized by (a) the appropriate choice of substituents in anchor in $\mathrm{RP}^{\mathrm{III}}\left[\mathrm{TeP}^{\mathrm{V}}(t \mathrm{BuN})(u\right.$ $\mathrm{N} t \mathrm{Bu})]_{2}(\mathrm{R}=\mathrm{Ad}, t \mathrm{Bu})$. $\mathrm{Te}_{\mathrm{m}}\left(\mathrm{P}^{\mathrm{III}} \mathrm{R}\right)_{\mathrm{n}}(\mathrm{m}=1: \mathrm{n}=2, \mathrm{R}=$ OMes*; $\mathrm{n}=3, \mathrm{R}=$ Ad; $\mathrm{n}=4, \mathrm{R}=\mathrm{Fc} ; \mathrm{m}=\mathrm{n}=$ 3: $\mathrm{R}=$ Trt, Mes*) 